\title{
SISTEM INFORMASI PENJADWALAN PEMBELAJARAN PADA SMAN 5 MATARAM
}

\author{
(Class Scheduling Information System of SMAN 5 Mataram)
}

\author{
Muhammad Syulhan Al Ghofany ${ }^{[1]}$, I Gede Pasek Suta Wijaya ${ }^{[1]}$, Novian Maududi ${ }^{[1,2]}$ \\ ${ }^{[1]}$ Dept Informatics Engineering, Mataram University \\ Jl. Majapahit 62, Mataram, Lombok NTB, INDONESIA \\ ${ }^{[2]}$ Sekolah Menengah Atas Negeri 5 Mataram \\ Jl. Udayana No. 2A, Kec. Selaparang, Mataram, Lombok NTB, INDONESIA \\ Email: muh.syulhan@gmail.com, gpsutawijaya@unram.ac.id, dodhie2015doa@gmail.com
}

\begin{abstract}
Abstrak
Penjadwalan mata pelajaran pada sekolah-sekolah saat ini masih dilakukan secara manual tanpa melibatkan proses komputasi sehingga kurang efektif karena parameter penyusun dan batasannya tentu sangat banyak, seperti waktu yang tersedia baik itu hari dan jam mengajar, ruangan, dan ketersediaan tenaga pengajar. Proses penjadwalan di SMAN 5 Mataram masih diolah secara manual dengan hanya menggunakan Excel, tentunya akan sangat memakan banyak waktu sehingga risiko kesalahan saat penyusunan dan hasilnya akan sangat tinggi. Dengan melihat permasalahan yang ada maka dibutuhkan suatu sistem informasi penjadwalan untuk meminimalkan kesalahan-kesalahan yang ada. Sistem informasi penjadwalan ini dibuat dengan suatu algoritma yang bernama algoritma genetika dan salah satu framework PHP yaitu Codeigniter yang sudah menyiapkan berbagai macam library untuk dapat mempermudah dalam pengembangan. Algoritma genetika merupakan salah satu solusi yang bisa digunakan untuk menyelesaikan permasalahan tersebut di mana algoritma ini didasarkan atas mekanisme dari seleksi alam yang dikenal dengan proses evolusi biologis seperti seleksi alam, pindah silang dan mutasi. Hasil yang didapatkan dengan adanya sistem ini yaitu memudahkan dalam proses penyusunan sehingga menghemat dari sisi tenaga yang mengurus jadwal terkait dan waktu yang awalnya memakan 2 minggu menjadi 2 hari, dan juga mendapatkan hasil yang sudah sesuai dengan yang diinginkan.
\end{abstract}

Keywords: Sistem Informasi, Penjadwalan, Codeigniter, Algoritma Genetika.

\section{Pendahuluan}

Penyusunan jadwal mata pelajaran pada lembaga penyelenggara pendidikan yang dilakukan secara konvensional tanpa melibatkan proses komputasi akan terasa tidak efektif jika terdapat banyak parameter dan batasan (constraint) yang digunakan, seperti jumlah jam (sesi) satu mata pelajaran yang dibolehkan dalam sehari, jumlah kelas, dan ketersediaan tenaga pengajar. Kesulitan seperti ini, dapat dipermudah dengan menggunakan sistem yang terkomputerisasi untuk mengelola data atau parameter yang akan digunakan nantinya dan juga peneliti mencoba melakukan pendekatan Algoritma Genetika terhadap sistem penjadwalan mata pelajaran sekolah [1].

Algoritma genetika cukup baik untuk digunakan dalam penjadwalan mata kuliah di sebuah sekolah. Algoritma genetika merupakan salah satu jalan untuk memecahkan masalah yang cukup besar dengan solusi yang cukup baik meskipun masalah tersebut membutuhkan waktu eksekusi yang lama bila dilakukan secara manual.

Tinjauan di lapangan bahwa sistem permasalahan penjadwalan di SMAN 5 Mataram masih diolah dengan hanya menggunakan Excel dengan peng-input-an manual. Pengolahannya dilakukan oleh satu orang staf tata usaha. Pada saat pembuatan jadwal tentunya memiliki risiko terjadinya kesalahan seperti kendala dalam hal ketepatan dan optimasi. Misal terjadinya tabrakan jadwal akibat adanya kelas majemuk dengan jumlah guru dan ruangan yang terbatas. Aspek penyebaran jadwal juga turut berpengaruh terhadap optimasi penjadwalan [2].

Berdasarkan permasalahan tersebut dapat dibuat sebuah "Sistem Informasi Penjadwalan Pada SMAN 5 Mataram" yang diharapkan mampu mengatasi kesalahan-kesalahan yang terjadi juga dapat memudahkan proses penjadwalan mata pelajaran pada SMAN 5 Mataram.

\section{TinjaUAn Pustaka}

Berikut adalah beberapa uraian-uraian yang saling berkaitan, mencakup bagian-bagian penting dari pembuatan sistem ini yang bersumber dari beberapa jurnal dan buku [3]-[12]. 
Pada penelitian tentang Sistem Informasi Penjadwalan dengan Metode Algoritma Genetika pada Laboratorium Teknik Informatika Universitas Muhammadiyah Maluku Utara [3], menyatakan bahwa penyusunan jadwal kegiatan praktikum di Teknik Informatika Universitas Muhammadiyah Maluku Utara masih secara manual sehingga mengalami kesulitan karena memiliki jumlah mahasiswa yang cukup banyak, dengan jumlah mahasiswa yang cukup banyak tentu dibutuhkan dosen yang memadai. Agar proses penjadwalan dapat dilakukan secara efektif dan efisien maka diperlukan suatu aplikasi yang bisa mempermudah proses penjadwalan yaitu aplikasi penjadwalan dan menerapkan algoritma yang tepat, salah satu algoritma bisa digunakan dalam aplikasi penjadwalan adalah Algoritma Genetika. Algoritma Genetika adalah algoritma pencarian yang didasarkan pada mekanisme seleksi alamiah dan genetika alamiah.

Penelitian tentang Implementasi Algoritma Genetika untuk Penjadwalan Mata Pelajaran pada LMS Getsmart [4], bahwa di LMS GETSMART yang merupakan platform e-learning belum memiliki fitur penetapan waktu. Melalui metode Algoritma Genetika dan dengan menggunakan data kendala yang ada, sistem ini mampu menghasilkan jadwal yang paling optimal berdasarkan nilai fitness yang diperoleh, karena algoritma ini menggunakan kombinasi prinsip seleksi alam dan prinsip ketegaran untuk mendapatkan hasil seperti yang diharapkan.

\subsection{Sistem Informasi}

Sistem informasi adalah sistem di dalam suatu organisasi yang mempertemukan kebutuhan pengolahan transaksi harian, membantu dan mendukung kegiatan operasi, bersifat manajerial dari suatu organisasi dan membantu mempermudah penyediaan laporan yang diperlukan [5].

\subsection{Sistem Penjadwalan}

Penjadwalan adalah sebuah proses dari penempatan tugas untuk sebuah kumpulan data jadwal. Penjadwalan mata pelajaran sekolah adalah suatu informasi yang menentukan mata pelajaran, hari dan jam dimulainya, ruang yang akan digunakan di mana akan membentuk suatu jadwal yang terstruktur dan tertata rapi sehingga kegiatan belajar dan mengajar dapat terselenggara dengan baik [5].

\subsection{Algoritma Genetika}

Algoritma genetika adalah suatu teknik pencarian dan teknik optimasi yang cara kerjanya meniru proses evolusi dan perubahan struktur genetik pada makhluk hidup. Prinsip utama dari cara kerja algoritma genetika ini diilhami oleh proses seleksi alam dan prinsip-prinsip ilmu genetika. Dalam seleksi alam, individu-individu bersaing untuk mempertahankan hidup dan melakukan reproduksi. Individu-individu yang lebih "fit" akan mempunyai peluang untuk terus bertahan hidup (survive) dan melakukan reproduksi (menghasilkan keturunan). Sebaliknya, individu-individu yang kurang "fit" akan mati dan punah (prinsip ini dinamakan juga "survival of the fittest"). Selanjutnya, dalam proses seleksi alam ini, beberapa individu baru yang lebih "fit" dari kedua orang tuanya akan "dilahirkan", melalui proses yang dinamakan penyilangan (cross-over) dan mutasi. Kedua proses ini terjadi pada kromosom-kromosom individu yang melakukan reproduksi. Proses seleksi dan reproduksi (penyilangan dan mutasi) ini berlangsung berkali-kali, sampai individu yang paling fit inilah yang merupakan solusi dari masalah yang dihadapi [6].

\subsection{MySQL}

MySQL adalah sebuah perangkat lunak sistem manajemen basis data SQL (bahasa Inggris: database management system) atau DBMS yang multithread, multi-user [7]. Dengan sekitar 6 juta instalasi di seluruh dunia. MySQL AB membuat MySQL tersedia sebagai perangkat lunak gratis di bawah lisensi GNU General Public License (GPL), tetapi mereka juga menjual di bawah lisensi komersial untuk kasus-kasus di mana penggunaannya tidak cocok dengan penggunaan GPL [8].

\subsection{PHP}

PHP (akronim dari PHP: Hypertext Preprocessor) adalah bahasa pemrograman yang berfungsi untuk membuat website dinamis maupun aplikasi web. Berbeda dengan HTML yang hanya bisa menampilkan konten statis, PHP bisa berinteraksi dengan basis data, file dan folder, sehingga membuat PHP bisa menampilkan konten yang dinamis dari sebuah website. Blog, Toko Online, CMS, Forum, dan Website Social Networking adalah contoh aplikasi web yang bisa dibuat oleh PHP. PHP adalah bahasa scripting, bukan bahasa berbasis tag seperti HTML. PHP termasuk bahasa yang lintas platform, ini artinya PHP bisa berjalan pada sistem operasi yang berbeda-beda (Windows, Linux, ataupun Mac). Program PHP ditulis dalam file plain text (teks biasa) dan mempunyai akhiran “.php” [9]. 


\subsection{Visual Studio Code}

Visual Studio Code adalah editor kode, suatu alat pengembangan lintas-platform dan multi-bahasa pertama dalam keluarga Microsoft Visual Studio yang dapat berjalan pada Windows, Linux, dan Mac OS X. VS Code merupakan alat kode-sentris, yang membuatnya lebih mudah untuk mengedit file kode dan sistem proyek berbasis folder serta menulis lintas-platform web dan aplikasi mobile untuk platform paling populer, seperti Node.js dan ASP baru Core NET. VS Code memiliki dukungan terintegrasi untuk sejumlah besar bahasa dan fitur pengeditan kaya seperti IntelliSense, menemukan referensi simbol, dengan cepat mencapai definisi jenis, dan banyak lagi [10].

\subsection{Codeigniter}

Codeigniter adalah sebuah web application framework yang bersifat open-source digunakan untuk membangun aplikasi php dinamis. Tujuan utama pengembangan codeigniter adalah untuk membantu pengembang (developer) untuk mengerjakan aplikasi lebih cepat dari menulis semua kode dari awal. Codeigniter menyediakan berbagai macam library yang dapat mempermudah dalam pengembangan. Codeigniter sendiri dibangun menggunakan konsep pola pengembangan Model-View-Controller. Codeigniter sangat ringan, terstruktur, mudah dipelajari, dan dokumentasi lengkap [11].

\section{8. ХАMPP}

XAMPP adalah perangkat lunak bebas, yang mendukung banyak sistem operasi, merupakan kompilasi dari beberapa program. Fungsinya adalah sebagai server yang berdiri sendiri (localhost), yang terdiri atas program Apache HTTP Server, MySQL database, dan penerjemah bahasa yang ditulis dengan bahasa pemrograman PHP dan Perl. Nama XAMPP merupakan singkatan dari X (empat sistem operasi apapun), Apache, MySQL, PHP dan Perl. Program ini tersedia dalam GNU General Public License dan bebas, merupakan web server yang mudah digunakan yang dapat melayani tampilan halaman web yang dinamis [12].

\section{Metode PelaksanaAn PKL}

Terdapat beberapa tahapan dalam pelaksanaan kegiatan Praktik Kerja Lapangan (PKL) di SMAN 5 Mataram untuk pembuatan sistem ini yaitu metode perancangan sistem, desain sistem, dan implementasi sistem.

\subsection{Metode Perancangan Sistem}

Model pengembangan yang digunakan pada pembuatan sistem informasi penjadwalan ini adalah model Waterfall. Model Waterfall adalah proses pengembangan perangkat lunak tradisional yang umum digunakan dalam proyek-proyek perangkat lunak yang paling pembangunan. Ini adalah model sekuensial, sehingga penyelesaian satu set kegiatan menyebabkan dimulainya aktivitas berikutnya. Hal ini disebut Waterfall karena prosesnya mengalir secara sistematis dari satu tahap ke tahap lainnya dalam mode ke bawah. Secara umum, model ini secara berurutan dan sistematis dimulai dari Communication, Planning, Modeling, Construction, dan Deployment [13].

\subsection{Desain Sistem}

Pada sistem informasi penjadwalan ini, perancangan sistem yang akan dibangun dapat dilihat dalam bentuk diagram. Adapun diagram tersebut terdiri dari usecase diagram, entity relationship diagram, sequence diagram dan activity diagram, berikut penjelasannya :

\subsubsection{Usecase Diagram}

Berikut ini merupakan Usecase Diagram dari Sistem Informasi Penjadwalan SMAN 5 Mataram yang ditunjukkan pada Gambar 1. Pada usecase diagram tersebut dapat dilihat bahwa hanya terdapat seorang aktor yang dapat menggunakan sistem tersebut. Pada sistem ini aktor merupakan anggota staf tata usaha pada SMA Negeri 5 Mataram. Hal pertama yang harus dilakukan aktor adalah melakukan login terlebih dahulu sebelum dapat melanjutkan aksi yang akan dilakukan. Setelah melakukan login, aktor dapat melakukan beberapa aksi seperti berikut :
a. Mengolah data guru
b. Mengolah data mata pelajaran
c. Mengolah data ruang
d. Mengolah data jam
e. Mengolah data hari
f. Mengolah data waktu tidak bersedia
g. Mengolah data pengampu 
h. Mengolah data penjadwalan

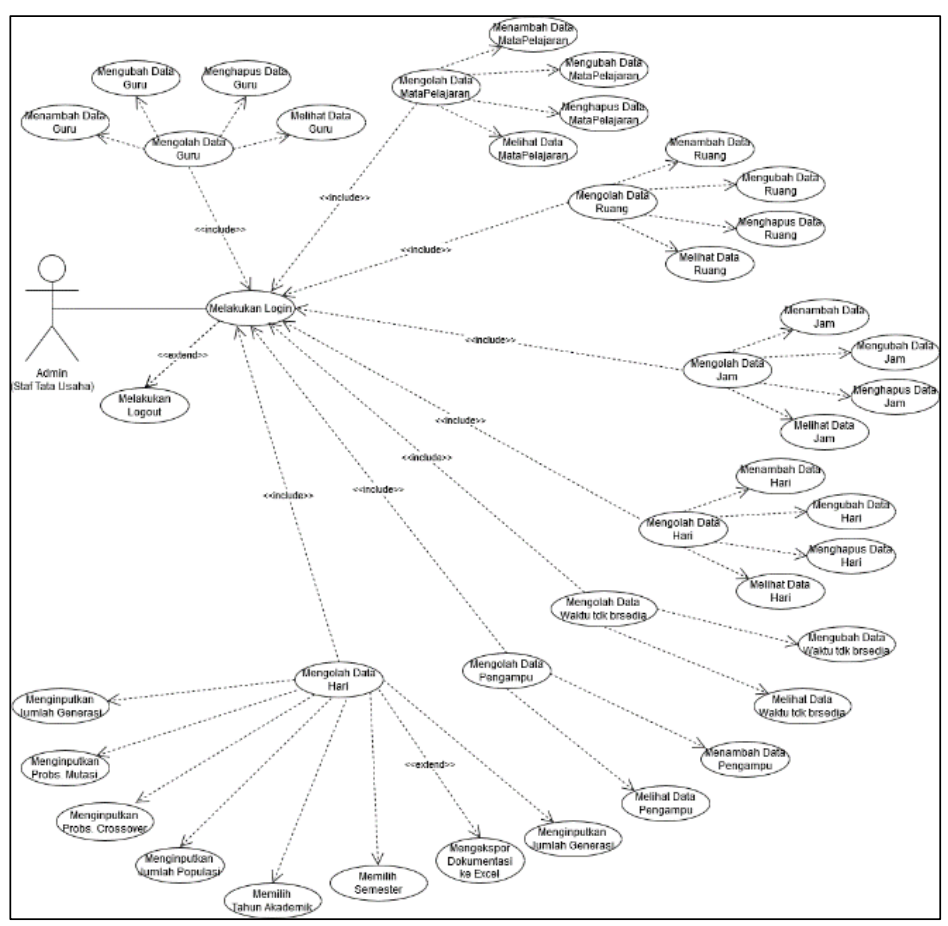

Gambar 1. Usecase Diagram

\subsubsection{Entity Relationship Diagram}

ERD menggambarkan hubungan relasi antar tabel [14]. Pada Gambar 2 di bawah menunjukkan ERD (Entity Relationship Diagram) dari Sistem Informasi Penjadwalan SMAN 5 Mataram di mana terdapat 9 entitas yaitu tabel guru, mata pelajaran, ruang, jam, hari, pengampu, waktu tidak bersedia, penjadwalan, dan user.

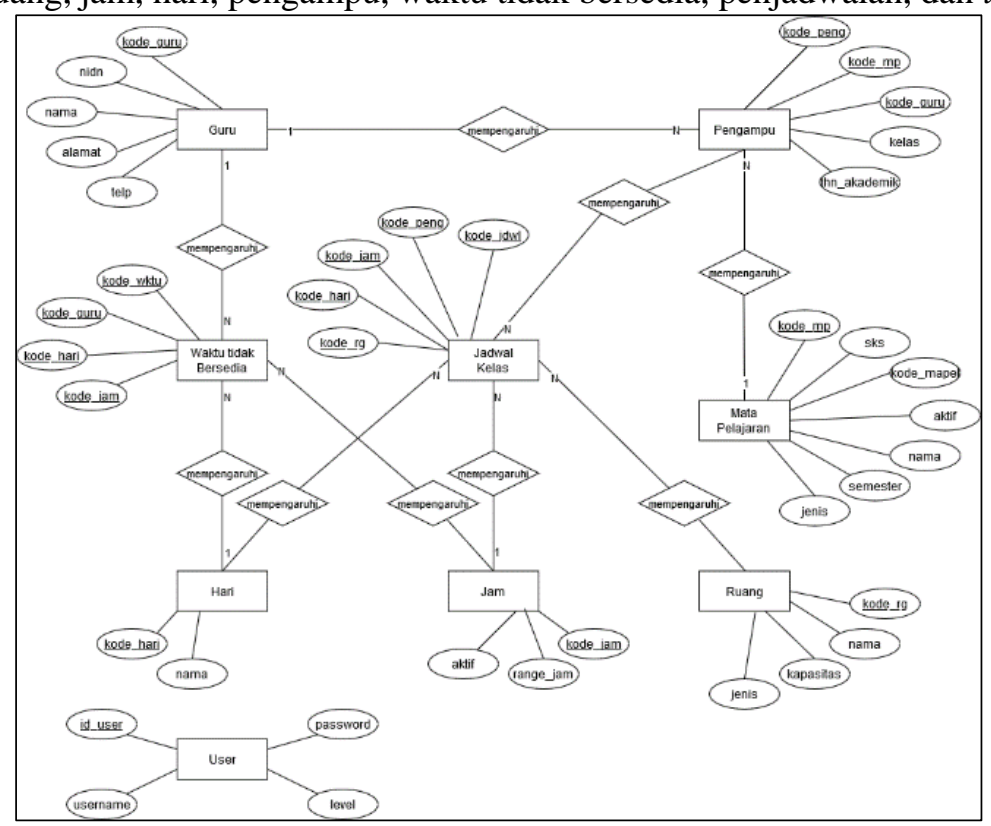

Gambar 2. Entity Relationship Diagram 


\subsection{Implementasi Sistem}

Implementasi sistem pada pembahasan ini mencakup implementasi sistem basis data yang disesuaikan dengan perancangan pada sub-bab sebelumnya. Berikut adalah implementasi sistem dari sistem informasi penjadwalan SMAN 5 Mataram.

a. Tabel guru ditampilkan pada Gambar 3 yang merupakan basis data guru yang digunakan untuk menyimpan data diri dari guru.

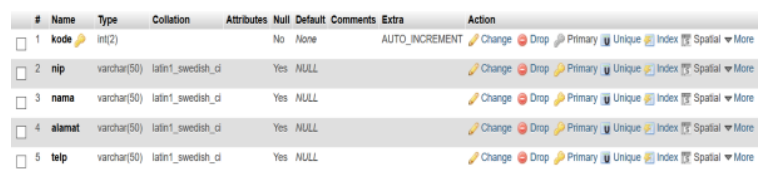

Gambar 3. Tabel Guru

b. Tabel mata pelajaran ditampilkan pada Gambar 4 yang merupakan basis data mata pelajaran yang digunakan untuk menyimpan data mata pelajaran.

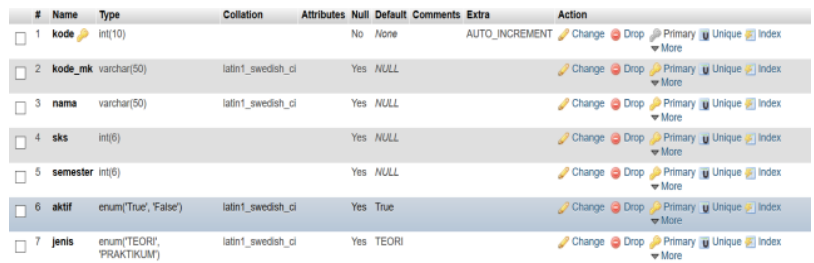

Gambar 4. Tabel Mata Pelajaran

c. Tabel ruang ditampilkan pada Gambar 5 yang merupakan basis data ruang yang digunakan untuk menyimpan data diri dari ruang.

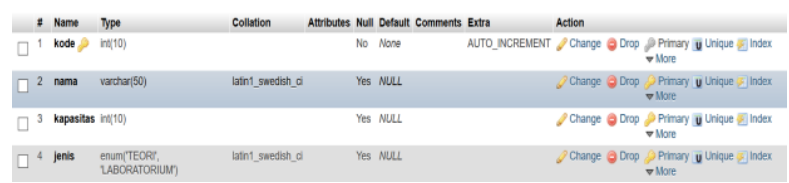

Gambar 5. Tabel Ruang

d. Tabel jam ditampilkan pada Gambar 6 yang merupakan basis data jam yang digunakan untuk menyimpan data jam.

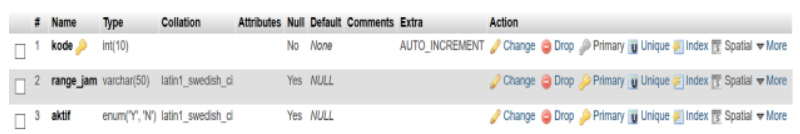

Gambar 6. Tabel Jam

e. Tabel hari ditampilkan pada Gambar 7 yang merupakan basis data hari yang digunakan untuk menyimpan data hari.

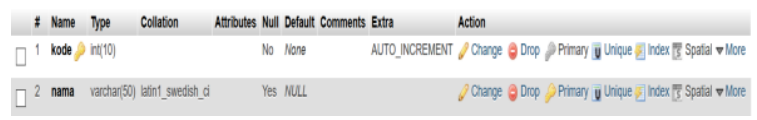

Gambar 7. Tabel Hari

f. Tabel waktu tidak bersedia ditampilkan pada Gambar 8 yang merupakan basis data waktu tidak bersedia yang digunakan untuk menyimpan data waktu tidak bersedia.

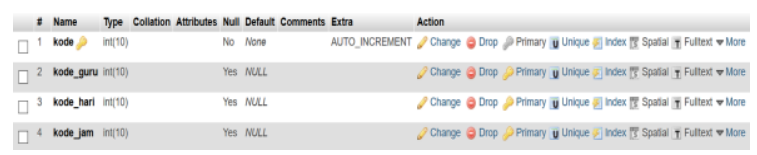

Gambar 8. Tabel Waktu Tidak Bersedia 
g. Tabel pengampu ditampilkan pada Gambar 9 yang merupakan basis data pengampu yang digunakan untuk menyimpan data pengampu.

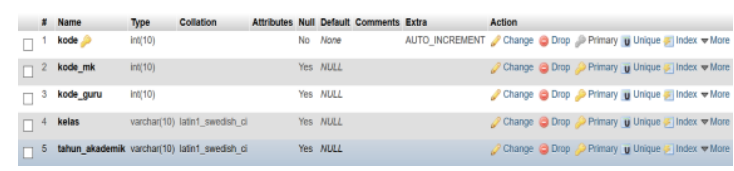

Gambar 9. Tabel Pengampu

h. Tabel penjadwalan ditampilkan pada Gambar 10 yang merupakan basis data penjadwalan yang digunakan untuk menyimpan data penjadwalan.

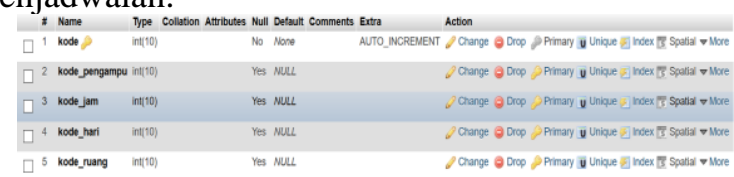

Gambar 10. Tabel Penjadwalan

i. Tabel user ditampilkan pada Gambar 11 yang merupakan basis data user yang digunakan untuk menyimpan data user.

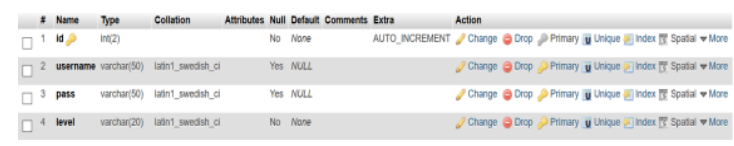

Gambar 11.Tabel User

\section{HaSil Dan PEMbahasan}

Bagian ini berisi hasil dan pembahasan mengenai sistem, yaitu hasil akhir sistem yang berisi tampilan-tampilan tiap menu dan hasil pengujian berupa wawancara dengan user. Berikut deskripsi dan pembahasannya.

\subsection{Hasil Akhir Sistem}

Berikut adalah tampilan-tampilan hasil akhir program dari Sistem Informasi Penjadwalan SMAN 5 Mataram beserta penjelasannya.

a. Pada Gambar 12 menampilkan halaman login yang merupakan implementasi dari halaman login. Halaman login ini merupakan halaman awal yang akan dikunjungi oleh user. Pada halaman ini berfungsi sebagai cara user untuk masuk ke dalam sistem dengan memasukkan username dan password yang sesuai dengan yang ada pada basis data.

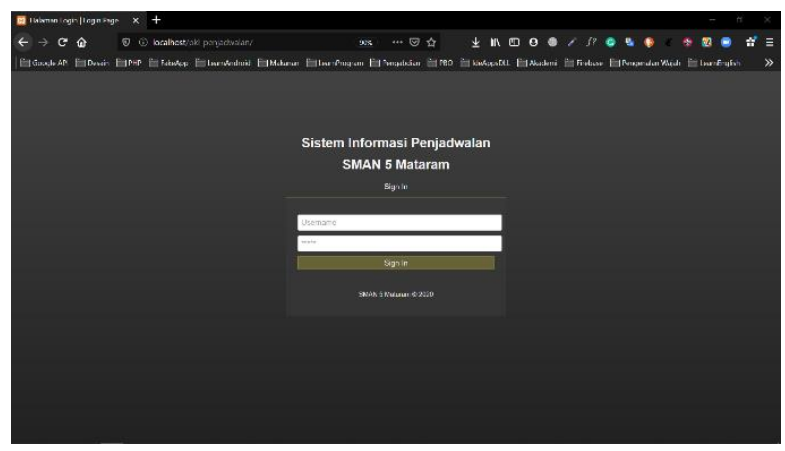

Gambar 12. Tampilan Login

b. Pada Gambar 13 menampilkan halaman beranda yang merupakan implementasi dari halaman beranda. Halaman beranda ini merupakan halaman awal yang akan dikunjungi oleh user setelah melakukan login. Pada halaman ini ditampilkan seluruh pilihan menu yang dapat dikunjungi. 


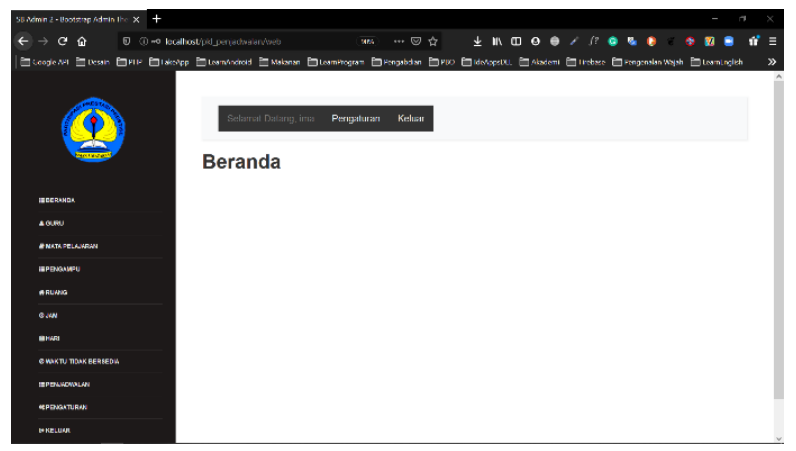

Gambar 13. Tabel Beranda

c. Pada Gambar 14 menampilkan halaman utama guru yang merupakan implementasi dari halaman utama guru. Halaman utama guru ini berfungsi untuk menampilkan semua data guru yang ada, juga terdapat button untuk menambahkan data guru baru yang nantinya akan diarahkan menuju form penambahan, user juga dapat melakukan pencarian guru, dan user juga dapat mengubah ataupun menghapus data yang ada dengan mengklik badge yang ada pada kolom paling kanan pada tabel data. Pada halaman ini ditampilkan seluruh pilihan menu yang dapat dikunjungi.

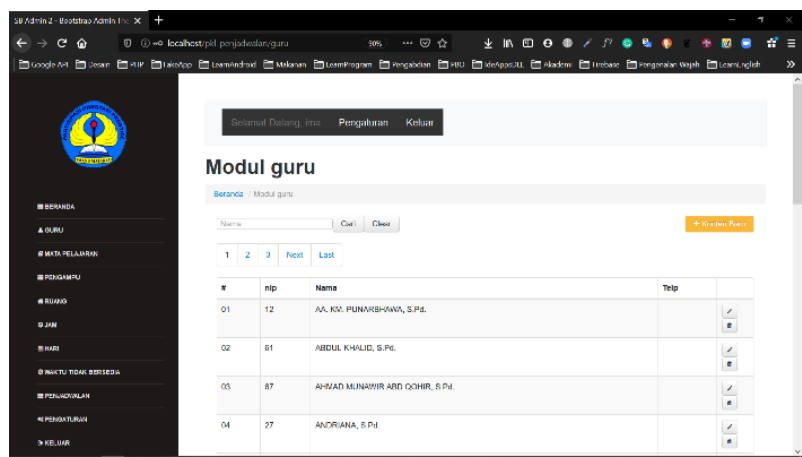

Gambar 14. Tampilan Utama Guru

d. Pada Gambar 15 menampilkan halaman utama mata pelajaran yang merupakan implementasi dari halaman utama mata pelajaran. Halaman utama mata pelajaran ini berfungsi untuk menampilkan semua data mata pelajaran yang ada, juga terdapat button untuk menambahkan data mata pelajaran baru yang nantinya akan diarahkan menuju form penambahan, user juga dapat melakukan pencarian mata pelajaran, dan user juga dapat mengubah ataupun menghapus data yang ada dengan meng-klik badge yang ada pada kolom paling kanan pada tabel data. Pada halaman ini ditampilkan seluruh pilihan menu yang dapat dikunjungi.

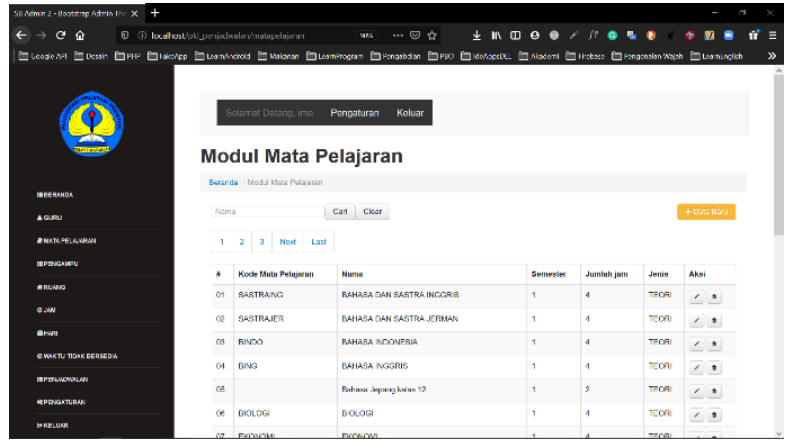

Gambar 15. Tabel Utama Mata Pelajaran

e. Pada Gambar 16 menampilkan halaman utama hari yang merupakan implementasi dari halaman utama hari. Halaman utama hari ini berfungsi untuk menampilkan semua data hari yang ada, juga terdapat button untuk menambahkan data hari baru yang nantinya akan diarahkan menuju form penambahan, dan user juga dapat 
mengubah ataupun menghapus data yang ada dengan meng-klik badge yang ada pada kolom paling kanan pada tabel data. Pada halaman ini ditampilkan seluruh pilihan menu yang dapat dikunjungi.

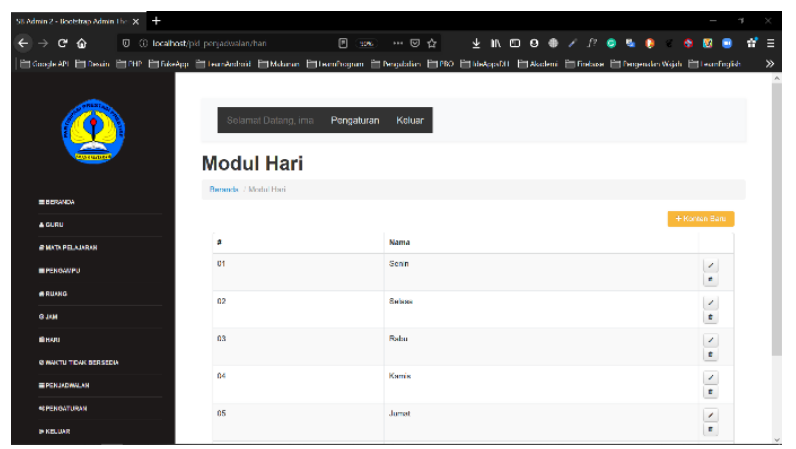

Gambar 16. Tampilan Utama Hari

f. Pada Gambar 17 menampilkan halaman utama ruang yang merupakan implementasi dari halaman utama ruang. Halaman utama ruang ini berfungsi untuk menampilkan semua data ruang yang ada, juga terdapat button untuk menambahkan data ruang baru yang nantinya akan diarahkan menuju form penambahan, dan user juga dapat mengubah ataupun menghapus data yang ada dengan meng-klik badge yang ada pada kolom paling kanan pada tabel data. Pada halaman ini ditampilkan seluruh pilihan menu yang dapat dikunjungi.

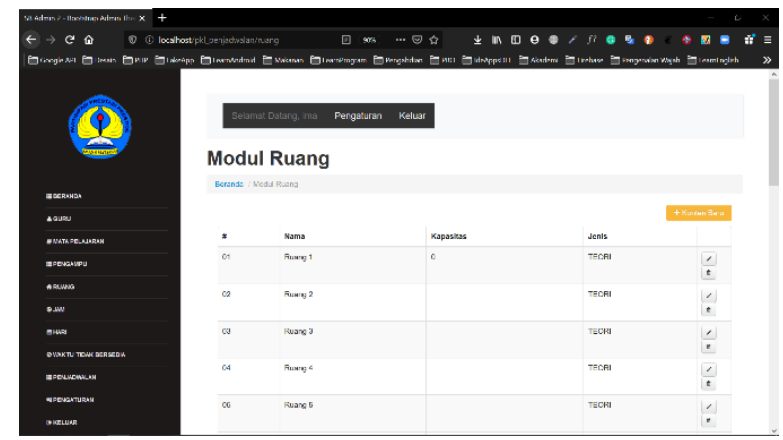

Gambar 17. Tampilan Utama Ruang

g. Pada Gambar 18 menampilkan halaman utama jam yang merupakan implementasi dari halaman utama jam. Halaman utama mata pelajaran ini berfungsi untuk menampilkan semua data jam yang ada, juga terdapat button untuk menambahkan data jam baru yang nantinya akan diarahkan menuju form penambahan, dan user juga dapat mengubah ataupun menghapus data yang ada dengan meng-klik badge yang ada pada kolom paling kanan pada tabel data. Pada halaman ini ditampilkan seluruh pilihan menu yang dapat dikunjungi.

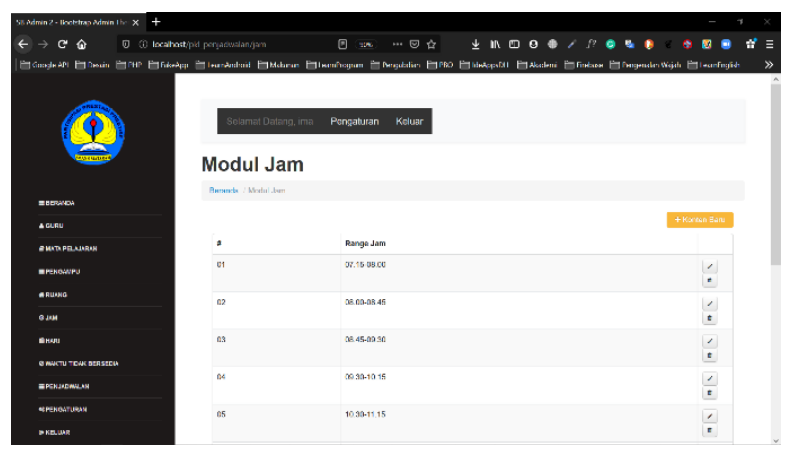

Gambar 18. Tampilan Utama Jam

h. Pada Gambar 19 menampilkan halaman utama pengampu yang merupakan implementasi dari halaman utama pengampu. Halaman utama pengampu ini berfungsi untuk menampilkan semua data pengampu yang ada dengan memilih semester dan tahun akademik, juga terdapat button untuk menambahkan data pengampu baru yang nantinya akan diarahkan menuju form penambahan, dan user juga dapat mengubah ataupun 
menghapus data yang ada dengan meng-klik badge yang ada pada kolom paling kanan pada tabel data. Pada halaman ini ditampilkan seluruh pilihan menu yang dapat dikunjungi.

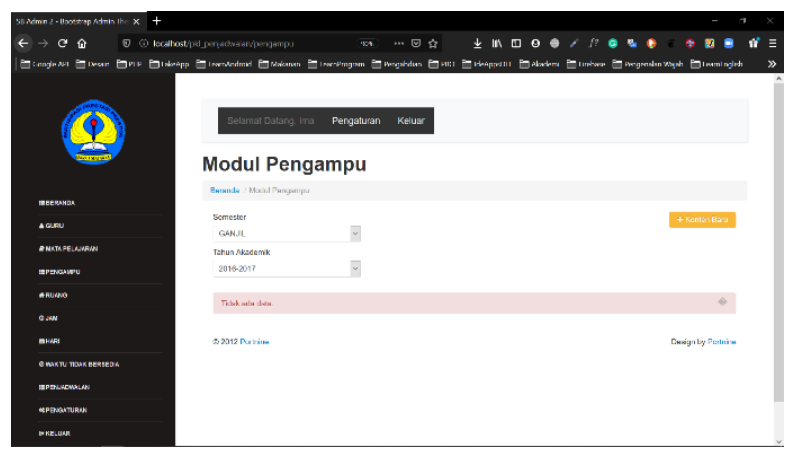

Gambar 19. Tampilan Utama Pengampu

i. Pada Gambar 20 menampilkan halaman waktu tidak bersedia yang merupakan implementasi dari halaman waktu tidak bersedia. Halaman utama waktu tidak bersedia ini berfungsi untuk menampilkan semua data waktu tidak bersedia dari guru yang dipilih, user dapat menambah waktu tidak bersedia dengan mencentang tidak bersedia pada kolom status, dan juga dapat menghapus waktu tidak bersedia dengan menghilangkan centangnya jika ada. Pada halaman ini ditampilkan seluruh pilihan menu yang dapat dikunjungi.

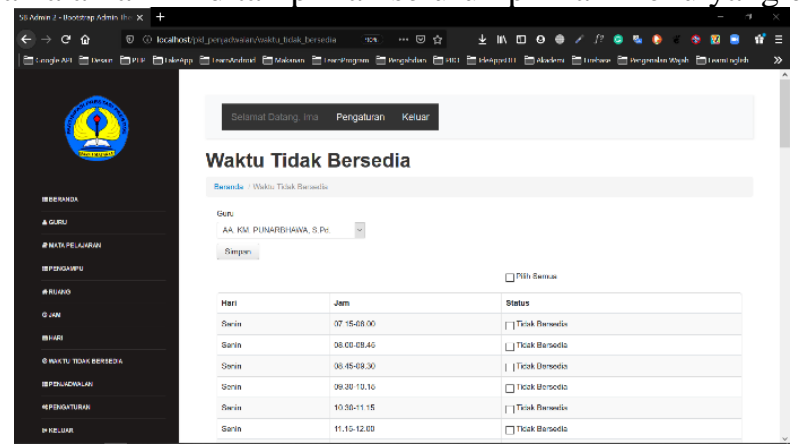

Gambar 20. Tampilan waktu tidak bersedia

j. Pada Gambar 21 menampilkan halaman penjadwalan yang merupakan implementasi dari halaman penjadwalan. Halaman penjadwalan ini berfungsi untuk menampilkan data hasil penjadwalan terakhir, user dapat melakukan proses penjadwalan dengan memilih semester dan tahun akademik lalu mengklik tombol proses, dan juga dapat mencetak hasil proses penjadwalan dengan meng-klik tombol export to excel. Pada halaman ini ditampilkan seluruh pilihan menu yang dapat dikunjungi.

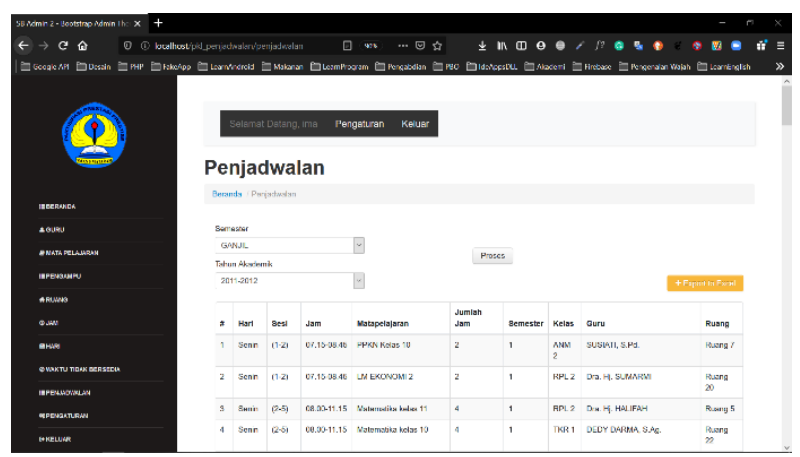

Gambar 21. Tampilan utama penjadwalan

\subsection{Hasil Pengujian}

Proses selanjutnya yang dilakukan setelah implementasi sistem yaitu dilakukan pengujian sistem. Sistem ini hanya akan digunakan oleh satu orang staf tata usaha SMAN 5 Mataram sehingga pengujiannya dilakukan dengan wawancara setelah melakukan percobaan menggunakan sistem. Pertanyaan saat wawancara yang dilontarkan yaitu:

a. Apakah sistem tersebut mudah untuk digunakan? 
b. Apakah sistem tersebut dapat dengan cepat melakukan proses penjadwalan sesuai dengan yang diharapkan?

c. Apakah sistem tersebut dapat membuat jadwal sesuai dengan apa yang diinginkan?

d. Apakah sistem tersebut dapat membantu dalam penyusunan jadwal untuk sekolah?

Setelah bertemu dengan user yang akan menggunakan sistem tersebut untuk melakukan wawancara, maka didapatkan jawaban berdasarkan pertanyaan-pertanyaan di atas seperti berikut:

a. Sistemnya mudah untuk digunakan, memang agak butuh sedikit waktu sembari mendengar penjelasan dari yang membuat sistem, tapi secara keseluruhan memang alurnya mudah dipahami terlebih desain sistemnya juga tidak terlalu ramai.

b. Memang agak butuh waktu sekitar 1-2 hari dari peng-input-an datanya hingga dilakukan proses penjadwalan oleh sistemnya, tapi itu sangat membantu mengurangi waktu yang dibutuhkan jika tidak menggunakan sistem yang bisa menghabiskan waktu sampai 2 minggu.

c. Setelah melakukan percobaan sekali, output jadwal sudah sesuai dengan yang diinginkan karena tidak ada jadwal yang bentrok.

d. Dapat sangat membantu, karena hanya satu orang yang mengurus pembuatan jadwal sehingga sistem ini dapat membantu pada sisi menghemat tenaga dan waktu.

\section{KESIMPULAN DAN SARAN}

\subsection{Kesimpulan}

Berdasarkan hasil Praktik Kerja Lapangan pada SMA Negeri 5 Mataram maka dapat diperoleh kesimpulan mengenai pembangunan Sistem Informasi Penjadwalan Pembelajaran sebagai berikut :

a. Sistem Informasi Penjadwalan pada SMAN 5 Mataram ini sangat membantu untuk menyelesaikan penjadwalan mata pelajaran, sehingga dapat menghasilkan jadwal yang lebih akurat dengan aturan yang ada dalam waktu yang lebih singkat.

b. Sistem ini dapat membantu user yaitu staf tata usaha dalam menyelesaikan permasalahan yang ada pada saat menyusun jadwal secara manual seperti waktu yang bentrok, tidak tersedianya ruangan, dan lain-lain.

c. Sistem ini efektif dalam penyusunan jadwal yaitu dari sisi waktu yang awalnya dapat memakan waktu 2 minggu menjadi 2 hari, dan juga menghemat dari sisi tenaga.

\subsection{Saran}

Sistem Informasi Penjadwalan pada SMAN 5 Mataram ini dibuat hanya berlaku untuk di tahun akademik pada saat itu dan beberapa tahun ke depan, dan juga terkadang untuk pemrosesan penjadwalan tidak mendapatkan hasil yang optimal pada awal percobaan, sehingga diharapkan dapat dikembangkan dengan menambahkan agar dapat tetap digunakan pada tahun akademik kapan pun dan untuk mendapat hasil yang lebih optimal mungkin bisa mencoba metode-metode yang lain selain dari Algoritma Genetika

\section{UCAPAN TERIMA KASIH}

Dengan ini penulis mengucapkan terima kasih kepada SMAN 5 Mataram yang sudah menerima penulis untuk melakukan penelitian dan dapat membuat program Sistem Informasi Penjadwalan untuk digunakan menyelesaikan permasalahan pembuatan penjadwalan di SMAN 5 Mataram, dan juga berterima kasih atas fasilitas dan ilmu-ilmu yang diberikan selama melakukan kegiatan PKL.

\section{DAFTAR PUSTAKa}

[1] R. A. V. Wiga Ayu Puspaningrum, Arif Djunaidy, "Penjadwalan Mata Kuliah Menggunakan Algoritma Genetika di Jurusan Sistem Informasi ITS," vol. 2, no. 1, pp. 127-131, 2013.

[2] A. L. Maharsi, "Sistem penjadwalan mata pelajaran sekolah menggunakan algoritma genetika," pp. 1-164, 2013.

[3] C. S. Agil Assagaf, Adelina Ibrahim, "Membangun Sistem Informasi Penjadwalan Dengan Metode Algoritma Genetika Pada Laboratorium Teknik Informatika Universitas Muhammadiyah Maluku Utar," J u r n a l I l m i a h I L K O M I N F O, vol. Vol.1, no. 2, pp. 95-105, 2018.

[4] L. A. Aditya, "Implementasi Algoritma Genetika untuk Penjadwalan Mata Pelajaran pada LMS GetSmart," $J$. Mantik Penusa, vol. 21, no. 1, pp. 65-70, 2017. 
[5] M. R. Fahmi et al., "Sistem Informasi Penjadwalan Mata Pelajaran pada Madrasah Tsanawiyah Ar Rohman Kencong."

[6] H. G. Yandra Arkeman, Kudang Boro Seminar, "Algoritma Genetika, Teori dan Aplikasinya untuk Bisnis dan Industri." 2016.

[7] A. Solichin, “MySQL Dari Pemula Hingga Mahir,” Univ. Budi Luhur, Jakarta, pp. 1-117, 2010.

[8] L. Y. Said, A. H. Jatmika, and I. W. A. Arimbawa, "Sistem Pendaftaran Hotspot Online Berbasis Web Menggunakan Mikrotik API, PHP, MySql Pada SMK Plus Nurul Hakim Kediri,” J. Teknol. Informasi, Komputer, dan Apl. (JTIKA ), vol. 1, no. 2, pp. 141-148, 2019, doi: 10.29303/jtika.v1i2.28.

[9] T. Yuliano, "Pengenalan PHP," Ilmiu Komput., pp. 1-9, 2007.

[10] D. A. Sole, "Visual Studio Code Succinctly," pp. 9-50, 2017.

[11] A. Basuki, "Membangun Web Berbasis PHP dengan Framework Codeigniter," Yogyakarta: Lokomedia, p. 212, 2010.

[12] R. V Palit, Y. D. Y. Rindengan, and A. S. M. Lumenta, "Rancangan Sistem Informasi Keuangan Gereja Berbasis Web Di Jemaat Gmim Bukit Moria Malalayang,” E-Journal Tek. Elektro Dan Komput., vol. 4, no. 7 , pp. 1-7, 2015, doi: 10.35793/jtek.4.7.2015.10458.

[13] I. Fahrurrozi and A. SN, "Proses pemodelan software dengan metode waterfall dan extreme programming: Studi kasus perbandingan," Univ. Gajah Mada, pp. 1-10, 2015.

[14] I. Tantowi, "Rancang Bangun Sistem Informasi TOEFL pada Pusat Bahasa Universitas Mataram,” J. Teknol. Informasi, Komputer, dan Apl. (JTIKA ), vol. 1, no. 2, pp. 216-223, 2019, doi: 10.29303/jtika.v1i2.56. 